\title{
The Contribution of Work Environment and Motoric Cognition on Work Readiness of Vocational High School Student
}

\author{
Fiskia Rera Baharuddin \\ Post-Graduate Program \\ Universitas Negeri Malang \\ Malang, Indonesia \\ Haris A. Syafrudie \\ Post-Graduate Program \\ Universitas Negeri Malang \\ Malang, Indonesia
}

\author{
Dwi Agus Sudjimat \\ Engineering Faculty \\ Universitas Negeri Malang \\ Malang, Indonesia \\ Husain Syam \\ Engineering Faculty \\ Universitas Negeri Makassar \\ Makassar, Indonesia
}

\begin{abstract}
This study aims to describe the input of the work environment (X1) and motoric cognition (X2), against the job readiness $(Y)$ either partially or simultaneously of vocational high school in Makassar city. The research method used an approach with survey method quantitative. The research conducted at the vocational high school in Makassar city. The samples used 200 students as respondents, grade XII Department of Mechanical. Data collected used observation for variable $X 1$, while variable $X 2$ and $Y$ used a questionnaire. Descriptive and regression using to analyse the data. The results revealed that: (1) the contribution of the work environment to the job readiness amount $57.8 \%$; (2) the input of motoric cognition to job readiness amount 32.7\%; and (3) the contribution of the work environment and motoric cognition simultaneously towards job readiness amount $38.5 \%$.
\end{abstract}

Keywords-work environment; motoric cognition; job readiness.

\section{INTRODUCTION}

Sustainable development can not be separated from national education activities. Education enables human resources to act dynamically and engage in development. Educational progress indicates the dynamics of social change in society. Quality human resources can be generated through education, with the provision of intelligence, skills, high work ethic, professional attitudes possessed, humans will be superior and have a global competitiveness. In connection with this, the focus of education is more directed in creating quality human resources from various disciplines, including education. The essence of teaching is an effort in improving the quality of human resources. The process of education in the School is expected to produce competent graduates. Education that produces competent graduates means increasing human capacity to compete with advanced nations Vocational High School graduates are projected to meet all the demands and needs of the industrial world as a middlelevel workforce, whose ideal is a labour force that is ready to use and can work in the industrial world. However, the existence of vocational education is still considered premature to be expected as a skilled and ready-made workforce graduate.

Vocational high school (VHS) is an instrument for the development of knowledge, attitude, and skills in the term of workforce preparation. The preparation should be kept up to date on the elaboration of the industry to produce graduates who needed by industry [1]. Vocational graduates are expected to meet all the demands and the needs of the world of work in a middle-level workforce. Graduates of VHS ideally is a readiness workforce and adaptable to work.

Reference [2] explained some survey which conducted in the United States have consistently shown that many senior high school graduates do not achieve the standards which set by the industry. It caused the effect of the irrelevant work environment in the school and the industry. Environmental factors also affect the performance of the brain, primarily in motoric cognition which instrumentally making good reflex movements as well as planned. The brain absorbs information from the surrounding environment, both at the level of conscious or unconscious. The brain prioritises stimuli such as colour, decorative elements, sounds, and smells [3].

The implementation of vocational learning particularly in the workshop, the role of motoric cognition can benefit from the skills and will affect to a job readiness of the learners. The desirable skills standards will not be reached if the student's performance decline, automatically the ability to achieve.

The work environment is the entire facility and infrastructure that is around employees who are doing the work that can affect the implementation of the work. The work environment is the overall means and infrastructure that is around employees who are doing the work itself. Also, physical work environment is a means and infrastructure associated with comfort in work. The physical work environment, including light illumination, the air temperature, humidity, air circulation, noise, mechanical vibrations, colour, decoration (layout), and workplace security. While nonphysical work environments are all related to labour relations that include tasks, job design, cooperation patterns, leadership patterns, and organisational culture.[4][5]

Motoric cognition usually triggered by an external stimulus, as the surrounding environment [6]. The surrounding environment such as colour, decorative elements, sounds and smells can affect the performance of learners in studying because the brain prioritises stimuli by learning environment [7].

The purpose of this study to describe the contribution of (1) the work environment to job readiness of vocational 

he motoric cognition to job readiness vocational students; and (3) the contribution of the workplace and motoric cognition simultaneously to job readiness of vocational students.

\section{METHOD}

This study uses a survey method with quantitative approach. The population of the research was students of grade XI Mechanical at public and private vocational school in Makassar city. The sample used random sampling amount 200 students. The variable of the research is the work environment $\left(\mathrm{X}_{1}\right)$, motoric cognition $\left(\mathrm{X}_{2}\right)$, and job readiness (Y).

The data was collected using questionnaires and observation sheets. The data were analysed using descriptive and inferential statistics. Analysis prerequisite test conducted including normality test, linearity test, and multicollinearity test before testing the hypothesis. Test hypotheses using regression analysis, namely: 1) simple linear regression analysis to determine the contribution of each independent variable on the dependent variable individually; and 2) multiple linear regression analysis to determine the contribution of the work environment and motoric cognition on work readiness.

\section{RESULT}

The results of the research described in the form of each variable. The description of the data presented in fig. 1 , fig 2 and fig 3 .

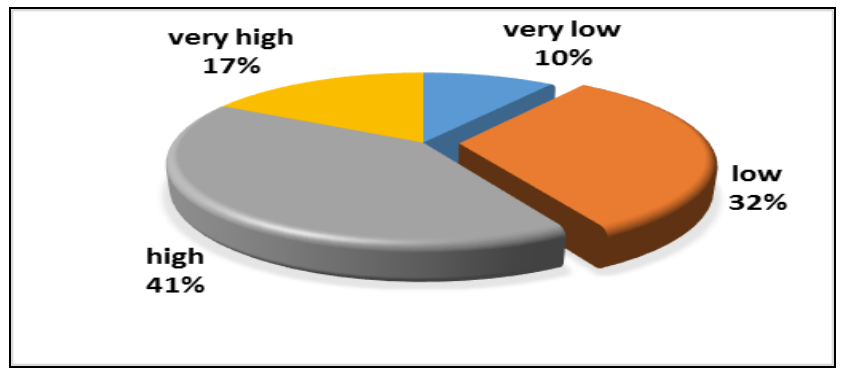

\section{Fig.1. Work Environment}

Figure 1 shows that the frequency distribution of the workplace in general $(41 \%)$ is rated highly by respondents. Furthermore, there are only $10 \%$ of respondents who considered that the work environment in the category is very low. The conclusion of data that the score for the work environment variables included in the high category.

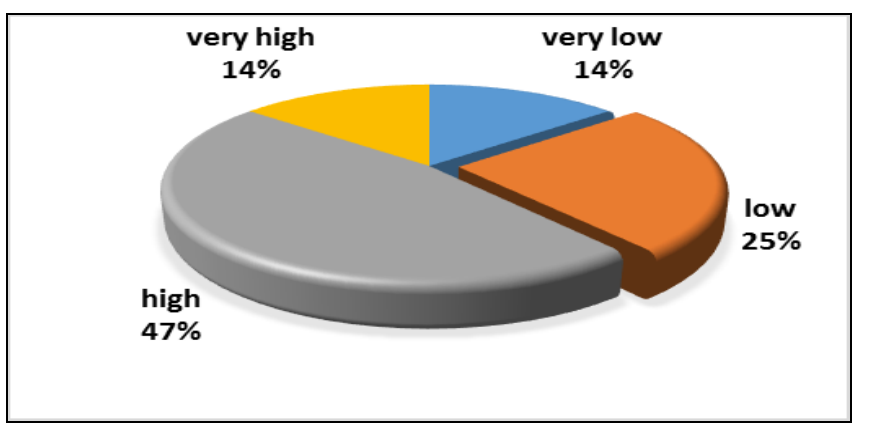

Fig 2. Kognisi motorik

Figure 2 explains that most respondents have high motor cognition (47\%) and a small percentage of respondents have very high motor cognition (14\%). The results of the analysis indicated that motor cognition of respondents in the very high category.

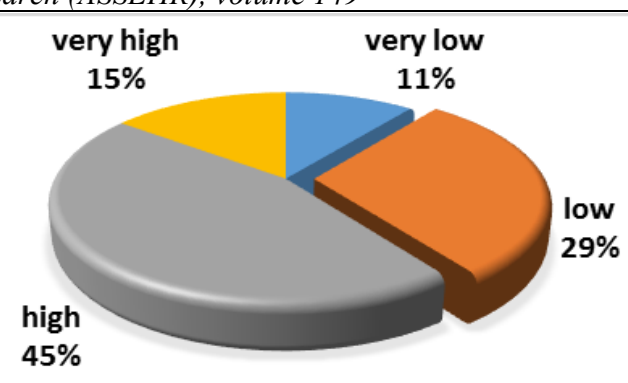

\section{Fig 3. Work Readiness}

Figure 3 shows that most students have high job readiness $(45 \%)$ and only $15 \%$ have very high job readiness. Thus, students' readiness is in the high category. The statistic description is presented in table 1 .

TABLE 1. DESCRIPTION DATA VARIABLE

\begin{tabular}{|c|c|c|c|c|c|c|}
\hline No & Var & Min & Max & Mean & St. Dev. & Rang \\
\hline 1 & $\mathrm{X}_{1}$ & 55 & 82 & 68.50 & 5.608 & 35 \\
\hline 2 & $\mathrm{X}_{2}$ & 57 & 79 & 70.25 & 5.985 & 32 \\
\hline 3 & $\mathrm{Y}$ & 72 & 87 & 84.30 & 4.275 & 27 \\
\hline
\end{tabular}

In Table 1 , shows that the standard deviation of $\mathrm{X}_{2}$ is greater when compared with a standard deviation of the variables $\mathrm{X}_{1}$ and $\mathrm{Y}$. However, the range of minimum and maximum values were higher in variable $X_{1}$.

Test requirements analysis performed including normality test, linearity test, and multicollinearity test described as follows:

TABLE 2. REQUIREMENTS ANALYSIS TEST

\begin{tabular}{|c|c|c|c|c|c|}
\hline \multirow{2}{*}{ No } & \multirow{2}{*}{ Var. } & \multirow{2}{*}{ Normality } & \multirow{2}{*}{ Linearity } & \multicolumn{2}{|c|}{ Multicollinearity } \\
\cline { 5 - 6 } & & & & Tolerance & VIF \\
\hline 1 & $\mathrm{X}_{1}$ & 0.286 & 0.000 & 0.770 & 1.246 \\
\hline 2 & $\mathrm{X}_{2}$ & 0.262 & 0.000 & 0.770 & 1.246 \\
\hline 3 & $\mathrm{Y}$ & 0.127 & & & \\
\hline
\end{tabular}

Table 2 shows that all the variables have a significant value (Asymp. Sig.) > 0.05. It means the data are usually distributed. Test for linearity obtained probability value (Asymp. Sig.) < 0.05; we conclude that the data distribution is linear which respect to Y. Multicollinearity experimental data by methods collinearity diagnostics indicate that the tolerance values $>0.1$ and VIF $<10$. It can be concluded that the research data do not have the nature of multicollinearity.

After the test meets the requirements of the analysis, the result of simple linear regression test for the first hypothesis and the second hypothesis present in Table 3.

TABle 3. Recapitulation Of First And SECOND Hypothesis TeSt

\begin{tabular}{|c|c|c|c|c|c|c|c|c|c|}
\hline \multirow{2}{*}{ Model } & $\begin{array}{c}\text { Uns. } \\
\text { Coefficients }\end{array}$ & \begin{tabular}{c} 
Stand. \\
Coef. \\
\cline { 2 - 9 }
\end{tabular} & $\begin{array}{c}\text { Std. } \\
\text { Error }\end{array}$ & Beta & Sig & $\mathbf{R}$ & $\begin{array}{c}\mathbf{R} \\
\text { Square }\end{array}$ & $\begin{array}{c}\text { Adjust } \\
\mathbf{R} \\
\text { Square }\end{array}$ & $\begin{array}{c}\text { Std. } \\
\text { The } \\
\text { error of } \\
\text { the est. }\end{array}$ \\
\hline $\mathrm{X}_{1}$ & 0.402 & 0.046 & 0.581 & 8.689 & 0.000 & 0.581 & 0.578 & 0.548 & 3.108 \\
\hline $\mathrm{X}_{2}$ & 0.398 & 0.047 & 0.620 & 6.235 & 0.000 & 0.625 & 0.327 & 0.472 & 3.390 \\
\hline
\end{tabular}

Table 3 shows the results of simple linear regression analysis with the regression coefficients for the variables work environment $\left(\mathrm{X}_{1}\right)$ to job readiness $(\mathrm{Y})$ is equal to 0.581 and have a positive value. The coefficient regression for variable motoric cognition $\left(\mathrm{X}_{2}\right)$ on job readiness $(\mathrm{Y})$ is equal to 0.620 and have a positive value. Both of these hypotheses has a significant probability value of $0.000(\mathrm{p}<0.05)$. It means that the first and second hypothesis can be accepted. 
Table 4.

TABLE 4. RECAPITULATION OF THIRD HYPOTHESIS TEST

\begin{tabular}{|c|c|c|c|c|c|c|c|c|}
\hline \multirow{2}{*}{ Model } & \multicolumn{2}{|c|}{$\begin{array}{c}\text { Uns. } \\
\text { Coefficients }\end{array}$} & \multirow{2}{*}{$\begin{array}{l}\text { Stand. } \\
\text { Coef. } \\
\text { Beta }\end{array}$} & \multirow{2}{*}{ Sig } & \multirow{2}{*}{$\mathbf{R}$} & \multirow{2}{*}{$\begin{array}{c}\text { R } \\
\text { Square }\end{array}$} & \multirow{2}{*}{$\begin{array}{c}\text { Adjust } \\
\mathbf{R} \\
\text { Square }\end{array}$} & \multirow{2}{*}{$\begin{array}{l}\text { Std. The } \\
\text { error of } \\
\text { the Est. }\end{array}$} \\
\hline & B & $\begin{array}{l}\text { Std. } \\
\text { Error }\end{array}$ & & & & & & \\
\hline 1 & & & & 0.000 & 0.722 & 0.594 & 0.425 & 3.002 \\
\hline $\mathrm{X}_{1}$ & 0.378 & 0.047 & 0.249 & 0.000 & 0.625 & & & \\
\hline $\mathrm{X}_{2}$ & 0.427 & 0.050 & 0.527 & 0.000 & 0.625 & & & \\
\hline
\end{tabular}

Table 4 shows the results of multiple linear regression between the variables $\mathrm{X}_{1}$ and $\mathrm{X}_{2}$ to $\mathrm{Y}$ simultaneously. The simultaneous regression coefficient is equal to 0.722 which means it has a strong influence because of approaching the number 1. It means that the working environment and motoric cognition of the students have a strong influence on job readiness. While the value of variable $X_{1}$ and $X_{2}$ is high, so was the value of $\mathrm{Y}$ variable. Significance probability value produced is equal to 0,000 and $<0.05$. It can be concluded that the third hypothesis is accepted. The amount of the contribution of the work environment and motoric cognition against to job readiness is $59.4 \%$.

\section{DISCUSSION}

Hypothesis testing results prove that there is a significant contribution to the work environment by $57.8 \%$ to increase job readiness skills of vocational students of machining techniques program in Makassar city. The motoric cognition contributes significantly to the work environment by $32.7 \%$ to increase job readiness skills of vocational students of machining techniques program in Makassar city. The higher of the student's knowledge about the work environment and motoric cognition, it will make higher of the students' job readiness.

The place of industrial work practices for vocational students is a place for students to know the working environment. It is used to prepare themselves to work on his skills after they graduate. Regarding [1], there is a significant relationship between the practice of school production units, industrial experience working practices, and family support for job readiness. Similarly, research conducted by reference [8], which revealed substantial relationship exists between employee performance with levels of employment and working conditions (physical work, the physical situation of the working environment and safety). In the vocational learning context, the work environment can shape the students' knowledge in developing job readiness that includes aspects of academic skills, technical skills, and values as well as the aspect of attitude to support the development of its potential. The results of the study support other researchers who concluded that the work environment contributes significantly to job readiness skills of vocational students.

Motoric cognition is a mental process that is involved planning, preparation, and production of a person's actions, as well as the mental processes that involved anticipation, prediction, and interpretation of the actions of others [9]. The brain absorbs information from the surrounding environment when the environment is not comfortable; then it can affect the performance of learners in studying the brain because the brain prioritises stimuli such as colour, decorative elements, sounds and smells [3]. The study results both theoretically and empirically by other researchers support the current findings in this study, so it can be concluded that the motoric cognition has contributed significantly to job readiness skills of vocational students.
The role of the work environment and motoric cognition in vocational learners is a picture and information about job readiness to enter the world of work. The introduction of the working environment to the student, it is expected that learners can acquire knowledge about the world of work replicas through motoric cognition and skills to prepare themselves for the world of work after their graduation.

\section{CONCLUSION ANDSUGGESTION}

This research indicated the contribution of the work environment on work readiness reached fifty-seven percent. This research also showed that there is a motor cognition contribution to job readiness by thirty-two percent. Ultimately, this research revealed that there is a significant contribution to the working environment and cognition motor simultaneously on the willingness of vocational students work packages machining engineering expertise in Makassar. An implication of this study can be a matter evaluation to caring student's work environment to be adjusted with the industry and work. The school should also arrange a program by involving the industry to the school so that the students get information and an overview of the industry.

\section{REFERENCE}

[1] S. Khasawneh, L. Khasawneh, S. Hailat, and M. Jawarneh, "University students' readiness for the national workforce: A study of vocational identity and career decision-making," Mediterr. J. Educ. Stud., vol. 12, no. 1, p. 27, 2007.

[2] M. Bangser, "Preparing High School Students for Successful Transitions to Postsecondary Education and Employment. Issue Brief.," Natl. High Sch. Cent., 2008.

[3] E. Jensen, Brain-based learning: The new paradigm of teaching. Corwin Press, 2008.

[4] M. Gerber et al., "Adolescents with high mental toughness adapt better to perceived stress: A longitudinal study with Swiss vocational students," Pers. Individ. Dif., vol. 54, no. 7, pp. 808-814, 2013.

[5] A. Buyukgoze-Kavas, R. D. Duffy, and R. P. Douglass, "Exploring links between career adaptability, work volition, and well-being among Turkish students," $J$. Vocat. Behav., vol. 90, pp. 122-131, 2015.

[6] G. S. Brager and R. J. De Dear, "Thermal adaptation in the built environment: a literature review," Energy Build., vol. 27, no. 1, pp. 83-96, 1998.

[7] M. H. M. Isa, M. Masrom, and K. R. Salim, "Review of Learning Models for Production Based Education Training in Technical Education," in Teaching and Learning in Computing and Engineering (LaTiCE), 2014 International Conference on, 2014, pp. 206-211.

[8] E. Kahya, "The effects of job characteristics and working conditions on job performance," Int. J. Ind. Ergon., vol. 37, no. 6, pp. 515-523, 2007.

[9] S. D. Phillips, D. L. Blustein, K. Jobin-Davis, and S. F. White, "Preparation for the school-to-work transition: The views of high school students," J. Vocat. Behav., vol. 61, no. 2, pp. 202-216, 2002. 